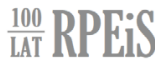

\author{
MAREK ŁAZOR*
}

\section{KILKA UWAG O WYKLADNI CELOWOŚCIOWEJ W PRAWIE OCHRONY ŚRODOWISKA}

\section{WPROWADZENIE}

Zasadniczą idea, która przyświeca niniejszemu opracowaniu, jest dążenie do odnalezienia argumentów przemawiających za uzasadnieniem tezy o wyjątkowej adekwatności derywacyjnej koncepcji wykładni prawa do interpretacji przepisów prawa ochrony środowiska, z uwagi zarówno na ogólną specyfikę wartości, do których się ono odwołuje, jak i inne szczególne właściwości, które temu właśnie prawu przypisuje dogmatyka prawnicza. Ujęcie metodologiczne przedmiotu badawczego będzie więc skupiać się przede wszystkim na aspekcie celowościowym tej wykładni, jako niezwykle doniosłym we wskazanej gałęzi prawa, a z uwagi na powiązania teoretycznoprawne w ograniczonym zakresie zostanie również zaprezentowany jej kontekst funkcjonalny. Poczynione w niniejszym artykule rozważania, choć będą miały charakter nader ogólny i nie wyczerpia zarysowanego obszaru badawczego, to moga stanowić pewien punkt wyjścia do głębszej analizy czy też dalszej dyskusji na ten temat w nauce prawa. Stanowisko takie poparte jest faktem, że - jak zauważa Bartosz Rakoczy - „problematyka wykładni prawa ochrony środowiska należy do jednych z najbardziej istotnych, a jednocześnie bardzo słabo opracowanych w doktrynie. Wykładnia prawa ochrony środowiska jest wykładnią specyficzna. Wprawdzie w teorii prawa podnosi się, że nie można mówić o odrębności wykładni poszczególnych gałęzi prawa (czy też jego działów), gdyż wykładnia jest jednolita dla wszystkich, jednak w poszczególnych dogmatykach prawniczych wyraźnie dostrzega się różnice, a przynajmniej pewne specyficzne cechy wykładni przepisów danej gałęzi lub działu"1.

Poza tym w nauce prawa ochrony środowiska, jak dowodzi przeprowadzona przez autora kwerenda, można w zasadzie zaobserwować deficyt publikacji

Marek Łazor, Uniwersytet Szczeciński, mareklazor@onet.pl, https://orcid.org/0000-0002-0074-9877

1 Rakoczy (2018): 87. 
naukowych, w których oprócz powoływania się na konkretną dyrektywę wykładni przy interpretacji tekstu prawnego, twórca opowiadałby się również za przydatnościa w tym procesie określonej koncepcji wykładni. W rezultacie w doktrynie prawa ochrony środowiska można generalnie dostrzec zjawisko nachylenia w kierunku apragamtycznego ujęcia wykładni (skupienia się na jej rezultacie), z ograniczonym podejściem do wykładni pojmowanej w kontekście pragmatycznym, czyli jako ciagu czynności, który zmierza do rekonstrukcji norm z przepisów prawnych oraz ma za zadanie ustalić znaczenie teksty normatywnego, gdy jest on niejasny. Marek Smolak trafnie przyjmuje, że wykładnia w znaczeniu pragmatycznym może być ujmowana jako „paradygmat interpretacyjnym”, gdyż stanowi „[...] aktualnie akceptowanych w kulturze prawniczej zespół wzorów czynności interpretacyjnych [...]. Oczywiście wzory te nie sa powszechnie obowiązujące, ale pewne rozstrzygnięcia interpretacyjne sa niedopuszczalne. Jak zaznacza T. Gizbert-Studnicki mamy tutaj do czynienia raczej z pewnymi wzorami uzasadnień rozstrzygnięć interpretacyjnych aniżeli wzory dochodzenia do tych rozstrzygnięć"'. W tym aspekcie trzeba zwrócić uwagę także na tezę sformułowaną przez Agnieszkę Choduń i Macieja Zielińskiego, iż interpretator „musi znać nie tylko brzmienie przepisów prawnych, ale przede wszystkim treść prawa, a do tego potrzebna jest zarówno znajomość zasad i dyrektyw wykładni (jakiejkolwiek koncepcji wykładni, która byłaby spójnym zespołem reguł opartych na wspólnym założeniu metodologicznym, a nie zbiorem różnego typu przypadkowych niepowiazanych ze sobą dyrektyw i maksym o różnym odniesieniu tematycznym stosowanych wybiórczo i ad hoc), jak i umiejętność posługiwania się nimi w praktyce interpretacyjnej”3. Na tej płaszczyźnie można postawić tezę, że w niektórych przypadkach zastosowanie reguł tej, a nie innej koncepcji wykładni, a nade wszystko wykorzystanie ich w sposób nie właściwy, może przesądzić o otrzymanym rezultacie końcowym w postaci nieprawidłowo zrekonstruowanej normy prawnej ${ }^{4}$.

Wykładnia to, według wielu przedstawicieli dogmatyki prawa, jeden z zasadniczych procesów stosowania prawa, a co za tym idzie - konkretyzacji jego norm w określonej rzeczywistości prawnej ${ }^{5}$. Doniosłość tej operacji w kontekście oceny prawidłowości otrzymanych wyników była zawsze wielopłaszczyznowym zagadnieniem teoretycznoprawnym. Wynika to z faktu, że - jak dostrzega nauka prawa - „reguły przekładu przepisów prawnych na normy, czyli reguły interpretacyjne (reguły wykładni), nie są na ogół ujęte w tekście prawnym, a co najwyżej spotyka się jakieś ogólnikowe przepisy (metaprzepisy), które wskazują pewien kierunek dokonywania wykładni przepisów danego systemu czy danej gałęzi prawa [...]. Reguły wykładni wytwarzała doktryna prawnicza w ciagu wielu wieków, ale są to reguły niejednokrotnie

${ }^{2}$ Smolak (1998): 24-25.

${ }^{3}$ Choduń, Zieliński (2020): 16.

${ }^{4}$ Por. Piszko (2002): 141-148.

${ }^{5}$ Zdaniem Czepity (2000: 193): „tylko w koncepcji Z. Ziembińskiego i »szkoły poznańskiej« interpretacja przepisów prawnych jest koniecznym etapem stosowania prawa”. 
sporne, niesprecyzowane i nie usystematyzowane"6. Jeden z wybitnych prawników okresu międzywojennego, Szymon Rundstein, ${ }^{7}$ analizując historyczne ${ }^{8}$ właściwości mechanizmu wykładni i wyznaczając niejako kierunki przyszłych badań, pisał, że „[...] tradycyjna hermeneutyka, nie wyjaśnia i nie wskazuje, kiedy i przy jakich warunkach, stosować należy te a nie inne sposoby wykładni. [...] Ustalenie więc zasad wykładni, bez wskazania konieczności i celowości stosowania owych prawideł w zależności od ukształtowania poszczególnego przypadku, brak - jednym słowem - wskazówek, dlaczego ten a nie inny "zabieg" interpretacyjny użyty być winien - pozbawia całą metodologię dawniejszą wszelkiej wartości”" W jednym ze swych wcześniejszych dzieł, odnosząc się do norm prawa administracyjnego, dostrzegał, że „cały szereg przepisów administracyjnych, ugruntowanych na prawnej podstawie, powstał i rozwinął się na podłożu rozumowań celowych. [...] Cel przyodziany został w suknię paragrafu - gdy inaczej wystapiłby w formie „faktycznego” rozumowania o potrzebie praktycznej"10.

Współczesna jurysprudencja dostarcza nam skonkretyzowanych schematów postępowania przy interpretacji przepisów prawa, które - jak już wskazano - można rozpatrywać w dwóch płaszczyznach badawczych: w ujęciu pragmatycznym i apragatycznym. W nauce prawa wyodrębnia się dwie podstawowe koncepcje wykładni: klaryfikacyjną i derywacyjna. Uwarunkowania interpretacyjne wynikające z derywacyjnej koncepcji wykładni prawa, zwłaszcza odnoszące się do jej aspektu celowościowego, zostaną omówione w dalszej części opracowania. Koncepcja klaryfikacyjna, której twórca jest Jerzy Wróblewski, opiera się na poprawnym ustaleniu rozumienia wyrażeń prawnych ${ }^{11}$. Stosownie do jej wytycznych wykładni nie stosuje się, jeśli norma prawna, która została zrekonstruowana z tekstu prawnego, jest jasna i może być rozumiana bezpośrednio, co odpowiada łacińskej paremii clara non sunt interpretand ${ }^{12}$. Koncepcja klaryfikacyjny wprowadza również zakaz dalszej interpretacji wtedy, gdy wykładnia językowa prowadzi do jednoznacznych wyników ${ }^{13}$. Doktryna prawa podkreśla, że w modelu tym nie wykształcono ,jednoznacznego schematu postępowania. Jest ona bardziej koncepcją opisowa, ukształtowana zwłaszcza na podstawie analizy pracy interpretacyjnej organów stosujacych prawo. Praca tychże organów jest tu traktowana jako modelowa sytuacja wykładni. [...] Na pytanie o to, czy i w jakim zakresie interpretacja klaryfikacyjna prowadzi do analizy aksjologicznej interpretowanego elementu prawa, można odpowiedzieć jedynie w konkretnym przypadku wykładni”"14. Zdaniem

${ }^{6}$ Wronkowska, Ziembiński (2001): 155.

7 Szymon Rudstein był znanym warszawskim adwokatem, doktorem Uniwersytetu w Heidelbergu i wykładowca Akademii Prawa Międzynarodowego w Hadze. Został zamordowany w obozie koncentracyjnym w Treblince w 1942 r. - szerzej Meszorer (1958): 89-93.

8 Por. Bogucki (2015): 34-52.

9 Rundstein (1916): 11-12.

${ }_{10}$ Rundstein (1904): 62-63.

11 Por. Romanowicz (2011): 55-74.

12 Por. Mikołajewicz( 2015): 77-89.

13 Por. Wróblewski (1961): 93-111.

14 Helios, Jedlecka (2018): 65. 
Wróblewskiego „wykładnia celowościowa obejmuje te wszystkie reguły, które w różny sposób nakazują uwzględnienie przy interpretacji przepisów szeroko rozumianego kontekstu społecznego, ekonomicznego, a także aksjologicznego systemu praw"15. Autora, poddając analizie właściwość, rolę i zadania dyrektyw interpretacyjnych, uważa, że ,jeżeli w procesie wykładni uwzględnia się cele prawa, to posługując się celem normy, należy ustalić go w ten sposób, by był zgodny co najmniej z celem instytucji, do której interpretowana norma należy. Jeżeli w procesie wykładni uwzględnia się oceny i reguły społeczne, to należy posługiwać się nimi jednolicie co najmniej w stosunku do wszystkich norm instytucji, do której interpretowana norma należy"16. Zbigniew Pulka, badając koncepcję klaryfikacyjną pod kątem stopnia działań optymalizacyjnych, stwierdza, że „nakaz uzyskania maksymalnego stopnia spójności aksjologicznej tekstu prawnego wyrażają dyrektywy nakazujące interpretatorowi zachowanie konsekwencji w posługiwaniu się nie tylko celem normy lub celem prawa (ratio legis lub ratio iuris), lecz także wartościami pozaprawnymi wyrażonymi w postaci pozaprawnych reguł społecznych, takich jak zasady współżycia społecznego czy też zasady słuszności”"

Warto zaznaczyć, że nauka prawa stoi na stanowisku, iż nie możemy obecnie mówić o konfrontacji względem siebie założeń koncepcji klaryfikacyjnej i derywacyjnej, a raczej zaobserwować można postępujący na wielu płaszczyznach proces ich zespalania, co w konsekwencji może doprowadzić w przyszłości do zbudowania ogólnej polskiej zintegrowanej teorii wykładni ${ }^{18}$. Zdaniem Choduń mechanizm ten w odniesieniu do koncepcji derywacyjnej opiera się generalnie na trzech filarach konsolidacyjnych. Jest nimi założenie, że „[...] wykładnia jest procesem przebiegającym zgodnie z treścią dyrektyw interpretacyjnych składajacych się na tę koncepcję, [...] przedmiotem wykładni jest tekst aktu prawnego [...], rezultatem (celem) wykładni jest norma prawna"19.

\section{ODTWARZANIE CELU NORMY PRAWNEJ A OGÓLNA SPECYFIKA WARTOŚCI W PRAWIE OCHRONY ŚRODOWISKA}

Na wstępie należy zaznaczyć, że wykładnia celowościowa zajmuje jedno z kluczowych miejsc w rekonstrukcji norm wchodzących w skład nie tylko w prawa ochrony środowiska, lecz także całego prawa administracyjnego. Podyktowane jest to ogólnym założeniem systemowym, że prawo to ma za zadanie służyć realizacji określonych celów. Według terminologii słownikowej „cel” to „planowany wynik każdego racjonalnego działania; to, do czego się dąży,

\footnotetext{
15 Wróblewski (1959): 313.

16 Wróblewski (1961): 98.

17 Pulka (2018): 84.

18 Zieliński, Zirk-Sadowski (2011): 99-111.

19 Choduń (2018): 95.
} 
o co zabiega" ${ }^{20}$. Tadeusz Kotarbiński wiąże cel ze skutecznościa, gdyż według niego skuteczne działanie to działanie prowadzace do skutku, który zamierzony jest jako cel ${ }^{21}$. Literatura przedmiotu stoi na stanowisku, że cel może być odtworzony na podstawie różnych płaszczyzn poznawczych. Marzena Kordela twierdzi, że cel prawa może być rozpatrywany historycznie albo aktualnie, może być to „[...] cel samego interpretatora czy nawet innych podmiotów. Jednakże celowość przypisuje się także pojedynczej normie w postaci ratio legis, jakiemuś zespołowi norm (np. instytucji), a także całemu systemowi prawa"22. Jednocześnie przy odtwarzaniu celu, jak trafnie zauważa Smolak, trzeba brać jeszcze uwagę fakt, „[...] że ustalenie celu tekstu prawnego oraz wskazanie, iż należy ten cel realizować, są dwiema odrębnymi czynnościami, a każda z nich wymaga odmiennego uzasadnienia" ${ }^{23}$. Według ogólnej typologii celów przedstawionej przez Gizberta-Studnickiego cele występujące w prawie ochrony środowiska możemy skategoryzować, jako cele mające przede wszystkim charakter długofalowy, których realizacja ,[...] nie polega na spowodowaniu powstania nowego stanu rzeczy, lecz raczej na chronieniu czy pielęgnowaniu czegoś" ${ }^{24}$.

Na bazie tych założeń w nauce prawa administracyjnego i orzecznictwie sądowoadministracyjnym wykształciła się tzw. koncepcja legalności celu, zgodnie z którą: „administracja nie powinna zmierzać w swoich działaniach wyłącznie do realizowania poszczególnych norm prawnych bez uwzględniania celów zakładanych przez prawodawcę. Często bowiem działania organów administracji moga pozostawać $\mathrm{w}$ zgodzie $\mathrm{z}$ literalnym brzmieniem przepisów, co więcej - być niesprzeczne z całym porządkiem prawnym, niemniej moga jednocześnie być niezgodne z ogólnym celem, dla którego dana norma lub cała ustawa zostały wydane. Cel może wynikać z oddzielnego przepisu, całej ustawy lub jej preambuły i wiąże tak samo jak konkretna norma, która stanowi podstawę prawną danego działania, stąd działanie niecelowe nosi równocześnie przymiot nielegalnego" ${ }^{25}$. W znacznej mierze w prawie administracyjnym ratio legis stanowionych przepisów skupia się w obszarze realizacji określonego celu publicznego. Zdaniem Wojciecha Jakimowicza: „celem publicznym administracji rozumianym szeroko jest już samo działanie administracji zdeterminowane prawnie i ukierunkowane na realizację interesu publicznego, a celem publicznym w wasskim rozumieniu jest pożądany wynik tego działania w postaci zrealizowania interesu publicznego o sprecyzowanym kształcie. O ile zrealizowanie celu publicznego zawsze oznacza zaspokojenie jakiegoś interesu publicznego, o tyle działanie $\mathrm{w}$ interesie publicznym nie zawsze musi doprowadzić do zaspokojenia tego interesu, co nie przekreśla faktu, że jest również działaniem realizującym cel publiczny" ${ }^{26}$. W tym aspekcie warto zaznaczyć,

\footnotetext{
${ }^{20}$ Dunaj (1996): 94.

21 Kotarbiński (1975): 104.

22 Kordela (2017): 150.

23 Smolak (2012): 51.

${ }^{24}$ Gizbert-Studnicki (1985): 57.

25 Wszołek (2011): 24.

26 Jakimowicz (2006): 155.
} 
że koncepcja interesu publicznego w prawie administracyjnym ma charakter wieloaspektowy i może być oparta między innymi na podstawach aksjologicznych, odwołujaccych się do danego katalogu wartości czy prakseologiczne wiążących ją z założonymi celami konkretnej regulacji prawnej ${ }^{27}$. W literaturze przedmiotu podejmuje się różnorakie próby zdefiniowania istoty interesu publicznego jako klauzuli generalnej obligujacej organy administracji publicznej do podejmowania czynności z punktu widzenia takich przesłanek, jak dobro ogółu, dobro wspólne, czy interes indywidualny ${ }^{28}$.

W doktrynie prawa od dłuższego czasu ugruntowane jest stanowisko, że samo środowisko może być pojmowane jako dobro wspólne, zadanie zaś jego ochrony jest obowiązkiem o charakterze administracyjnoprawnym ${ }^{29}$, obejmującym wszystkie jego elementy składowe. Piotr Korzeniowski słusznie zauważa, że „nie można stawiać znaku równości pomiędzy pojęciem środowiska a pojęciem środowiska jako dobra wspólnego ${ }^{30}$. Każdorazowe powoływanie się na dobro wspólne w odniesieniu do środowiska wymaga wykazania, że mamy do czynienia ze środowiskiem chronionym w interesie publicznym" ${ }^{31}$. Literatura przedmiotu zauważa, że ochrona tego interesu jest jednym $\mathrm{z}$ fundamentalnych celów, przed którym stoi prawo ochrony środowiska ${ }^{32}$, jego realizacja zaś leży w sferze kompetencji organów administracji publicznej, które powołane są również do jego harmonizacji z interesem indywidualnym ${ }^{33}$. Rakoczy dostrzega, że konflikt interesu publicznego z indywidualnym jest charakterystycznym atrybutem prawa ochrony środowiska i że może on czasami przybierać bardziej złożoną formę niż w innych dziedzinach prawa, jako na przykład konflikt dwóch sprzecznych ze sobą interesów publicznych czy też prywatnych $^{34}$. Na aspekt swoistej kolizji aksjologicznej w tej dziedzinie prawa zwraca uwagę także Gizbert-Studnicki, który odnotowuje, że zagwarantowanie ochrony środowiska może z reguły stawiać przed organem stosujacy prawo dylemat interpretacyjny związany z koniecznością rozstrzygnięcia konfliktu z innymi dobrem prawnie chronionym, takim jak na przykład rozwój działalności produkcyjnej zaspokajającej potrzeby społeczne ${ }^{35}$.

W związku ze sformułowanymi na wstępie opracowania założeniami badawczymi należy zaakcentować, że to nie tylko sam rodzaj celów występujących w obszarze prawa ochrony środowiska, ale przede wszystkim ogólna specyfika wartości, do których te cele się odnosza, pozwala nam spojrzeć pod innym kątem na funkcje wykładni celowościowej w tej dziedzinie prawa. Aby odwołać się na wstępie do poglądów filozofii prawa na temat wartości, to sa one ogólnie ujmowane jako „to, co godne jest, aby o nie zabiegać; to, co sta-

\footnotetext{
${ }^{27}$ Komierzyńska, Zdyb (2016): 161-179.

28 Szerzej Żurawik (2013): 60-62.

29 Jastrzębski (1976): 122.

30 Por. Lipowicz (2017): 17-31.

31 Korzeniowski (2015): 29.

32 Ciechanowicz-McLean (2007): 452-459.

33 Por. Stelmasiak (1994): 243, a także (2013).

34 Rakoczy (2018): 22.

35 Gizbert-Studnicki (1989): 1.
} 
nowi cel ludzkich pożądań lub dążeń albo - innymi słowy - to, co w istotnym stopniu bierze się pod uwagę przy podejmowaniu decyzji praktycznych" 36 . Jan Zimmermann uważa, że wartości stanowią aksjologiczną podstawę nie tylko tworzenia prawa, ale i jego stosowania ${ }^{37}$. W konsekwencji to samo pojęcie tak zwanego wartościowania utożsamiane jest z „ocenianiem”38. W kontekście schematu podejmowanych czynności interpretacyjnych należy w pełni przychylić się do poglądu Smolaka, że „[...] interpretator, po pierwsze, musi zidentyfikować cele/wartości, jakie moga być brane pod uwagę przy uzasadnianiu decyzji; po drugie, interpretator musi określić kryterium wyboru celów/ wartości uzasadniajacych decyzję; po trzecie, musi wykazać, że te, a nie inne wybrane wartości najpełniej uzasadniaja jego decyzję preferencji. [...] Stosuje [on - M.モ.] dyrektywę preferencji uwzględniająca pierwszeństwo stosowania dyrektywy celowościowej, uzasadnia swój wybór wartością prawa, którą jest celowość ujmowana w dwóch istotnych jej aspektach: jako wartość samoistna oraz jako wartość instrumentalna" ${ }^{39}$. Z tej perspektywy warto zaznaczyć, że w prawoznawstwie ugruntowany jest pogląd, że odniesienie do jakiegoś zakładanego system wartości nabiera szczególnego znaczenia, jeśli dążymy do uzasadnienia dyrektyw celowościowych w aspekcie ocennym, zwłaszcza gdy koszty ewentualnych działania i wartość skutków ubocznych nie moga być sprowadzone do zera, jak też gdy zakładane przez nas prawidłowości maja charakter jedynie prawdopodobny ${ }^{40}$. Z taką sytuacją mamy dość często do czynienia w prawie ochrony środowiska, gdy organowi administracji publicznej bez odniesienia do pewnego systemu wartości trudno byłoby dokonać prawidłowej rekonstrukcji normy prawnej, gdy na przykład na etapie wydania decyzji środowiskowej ${ }^{41}$ niemożliwe okazuje się jednoznaczne oszacowanie lub całkowite wykluczenie rozmiaru szkód środowiskowych, które może wywołać na danym obszarze określone przedsięwzięcie. W następstwie tego Korzeniowski słusznie uważa, że „wartości (normy) w prawie ochrony środowiska mogą być identyfikowane z celami ochrony środowiska oraz powinny być wykorzystywane jako instrument oceny prawa obowiąującego" 42 .

Analizowana w niniejszym artykule wyjątkowa przydatność derywacyjnej koncepcji wykładni prawa do odtwarzania celów w prawie ochrony środowiska wynika między innymi z faktu, że jest ona - jak podkreśla doktryna prawa modelem interpretacyjnym o dużym potencjale adaptacyjnym, przez co odpowiada aktualnym potrzebom praktyki prawniczej, jak i wpisuje się w nurt obowiąującej kultury prawnej. Olgierd Bogucki, analizując jej uwarunkowania teoretycznoprawne, zaznaczył, że „[...] cele nie stanowią [w niej - M.Ł.] odrębnej kategorii, lecz są szczególnego rodzaju wartościami, wyróżnionymi ze względu na to, że zrealizowanie ich ma być osiagnięte w największym stopniu

\footnotetext{
${ }^{36}$ Kwiecień (2011): 178.

37 Zimmermann (2015): 13.

38 Wróblewski (1973): 177.

39 Smolak (2014): 11.

40 Zieliński, Ziembiński (1998): 145-146.

41 Por. Barczak, Łazor, Ogonowska (2018): 78-94.

42 Por. Korzeniowski (2012): 250-251.
} 
przez ustanowienie określonych norm. Cele te jednak mają być realizowane przy uwzględnieniu innych, istotnych w danym przypadku wartości. W związku z tym po ustaleniu celów konieczne jest ustalenie również innych wartości” ${ }^{43}$. Autor wychodzi ponadto z założenia, że występujący w danej dziedzinie prawa system wartości ma z reguły charakter struktury „składnikowej”, co oznacza, że uformowany jest z wartości prostych, które budują wartości bardziej złożone i systemowe uporządkowania ocen globalnych, będące swoistymi „nienazwanymi wartościami”, które [...] wiążą ze sobą różne wartości i umożliwiaja porównywanie alternatyw z punktu widzenia tychże „nienazwanych wartości" ${ }^{44}$. Opisaną strukturę wartości możemy odnaleźć w systemie prawa ochrony środowiska, ich analiza zaś uwidacznia nam cele, którymi kierował się prawodawca przy konstruowaniu określonych regulacji prawnych. Odnoszą się one do warunków korzystania z zasobów środowiska i ukształtowały się w wyniku coraz bardziej różnorodnego wpływu człowieka na jego poszczególne elementy, takie jak na przykład klimat, szata roślinna czy zwierzęca lub gleba. Ze względu na zasięg występujących zanieczyszczeń i często ich transgraniczny charakter wartości, na których zbudowane sa prawne obowiazki ochrony środowiska, podlegają w polskim systemie prawnym procesowi unifikacji z wartościami występującymi nie tylko w obszarze prawa unijnego, lecz także międzynarodowego prawa publicznego. W konsekwencji tego Korzeniowski zasadnie uważa, że: „normy prawne chroniące środowisko służą realizacji pewnych wartości, które mają charakter uniwersalny. Należą do nich: zrównoważony rozwój, bezpieczeństwa ekologicznego, środowisko jako dobro wspólne oraz sprawiedliwość ekologiczna. [...] Wartości w prawie ochrony środowiska stanowią najczęściej kryterium lub zasadę wyboru celu, funkcji prawa oraz zadań ochronnych" ${ }^{45}$. Jan Boć, badajac przebieg normatywizacji wartości w tej dziedzinie prawa, dostrzega, że ,akurat w podstawowych ustawach polskich majacych za przedmiot ochronę środowiska nie widać bezpośredniego nazwania wartości na wzór areng konstytucyjnych, ale wprowadzone w nich zakazy i nakazy ewidentnie, choć dorozumiane, odnoszą się do regulacji istotnych społecznie wartości etycznych, bezpośrednio wskazują na szczególnie cenne dobra, określają cele administrowania, rysują ważne zadania publiczne, zobowiązują do szczególnego postępowania" ${ }^{46}$. Patrząc systemowo należy nadmienić, że najbardziej doniosłe wartości w prawie ochrony środowiska zostały wyrażone w formie zasadach ogólnych tego prawa ${ }^{47}$. Zbigniew Bukowski, podejmując próbę zakreślenia aksjologicznych podstaw jego stanowienia, eksponuje trzy główne wartości kształtujące ten proces. Jego zdaniem są nimi środowisko i ochrona środowiska, bezpieczeństwo ekologiczne i zrównoważony rozwój ${ }^{48}$.

Podsumowujac rozważania dotyczące ogólnej specyfiki wartości występujących w systemie prawa ochrony środowiska, trzeba wyraźnie zaznaczyć, że

\footnotetext{
43 Bogucki (2010): 196.

44 Bogucki (2020): 99 i 107.

${ }^{45}$ Korzeniowski (2017): 246-247.

${ }^{46}$ Boć (2015): 20.

47 Szerzej Korzeniowski (2010).

48 Bukowski (2017): 233-241.
} 
w kontekście skali rozwoju gospodarczego i tym samym poszerzania granic ingerencji człowieka w otaczające go ekosystemy wartości te podlegają procesowi ciagłej transformacji. Z tej przyczyny pojawiające się w tej gałęzi prawa „nowe” wartości sa z reguły odpowiedzią na zmienne formy zagrożeń środowiskowych. Stanowia one nie tylko fundament normatywizacji nowych instrumentów prawnych, ale także mogą modyfikować już istniejące instytucje prawne. Dynamika opisanych przemian stawia przed interpretatorem konieczność stosowania reguł takiej koncepcji wykładni, która w możliwie precyzyjny sposób zagwarantuje odtworzenie celu normy prawnej przy jednoczesnym zachowaniu $\mathrm{w}$ procesie interpretacji możliwe szerokiej perspektywy aksjologicznej, biorąc pod uwagę chociażby spójność jej wyniku z celami określonymi przez prawodawcę unijnego. Globalny charakter środowiska - a w konsekwencji potrzeba jego kompleksowej ochrony - wymaga, aby cele te się ze sobą zaziębiały, a w następstwie tego, by stosowane instrumenty prawne zarówno na szczeblu normatywnym prawa krajowego, jak i międzynarodowego były ze sobą zgodne i się uzupełniały.

Prześledzenie w następnej części opracowania głównych założeń metodologicznych odnoszących się do regu ${ }^{49}$ wykładni celowościowej w derywacyjnej koncepcji wykładni prawa pozwoli nam w sposób ogólny ocenić, czy może być ona przydatnym narzędziem do odtwarzania celów w prawie ochrony środowiska.

\section{WYKŁADNIA CELOWOŚCIOWA I FUNKCJONALNA Z PERSPEKTYWY DERYWACYJNEJ - ZARYS OGÓLNY}

Derywacyjna koncepcja wykładni prawa, której podwaliny opracował Zygmunt Ziembiński, a która następnie rozwijał Maciej Zieliński ${ }^{50}$, jest normatywną koncepcją wykładni51. Oznacza to, że opiera się ona na rzeczywistych cechach tekstów prawnych, w których budowie wyodrębnia się przepis prawny i normę prawna. W sposób kompleksowy standaryzuje ona zaprojektowane dyrektywy interpretacyjne, co w konsekwencji pozwala nam na wyodrębnienie normy zupełnej o ,jednoznaczności możliwej do osiagnięcia w realnym języku"52. Stopień ważności danej dyrektyw przesądza o jej zaklasyfikowaniu jako zasady, reguły bądź wskazówki, a uszeregowanie w określonym przez jej autora schemacie postępowania daje gwarancje właściwej rekonstrukcji normy prawnej ${ }^{53}$. Proces interpretacji dokonuje się w trzech następujących po sobie fazach: fazie porządkującej ${ }^{54}$, rekonstrukcyjnej ${ }^{55}$ i percepcyjnej ${ }^{56}$. Jeśli

\footnotetext{
49 Szerzej Zieliński (1998): 1-20.

50 Zieliński (2006): 94.

51 Choduń (2015): 111-125.

52 Zieliński, Zirk-Sadowski (2011): 3.

53 Zieliński (2012): 286-293.

54 Por. Kanarek, Zieliński (2001): 1-12.

55 Por. Mularski (2017): 7-46.

56 Zieliński (2012): 314-344.
} 
chcielibyśmy ogólnie scharakteryzować istotę tego procesu, to zdaniem Zielińskiego: „w ścisłym znaczeniu tego terminu wykładnia, czyli interpretacja tekstów prawnych, nazywa się operację myślowa, w toku której dokonuje się przekładu zbioru przepisów ogłoszonych w aktach prawodawczych na zbiór norm postępowania równoznaczny jako całość z danym zbiorem przepisów. Inaczej mówiąc, w toku wykładni (jeśli zostanie ona konsekwentnie doprowadzona do końca) dokonuje się przyporządkowania różnokształtnym przepisom prawnym - norm postępowania rozumianych w jakiś jeden, dostatecznie określony sposób" 57 .

Bogucki, nakreślając syntetyczny schemat postępowania interpretacyjnego w derywacyjnej koncepcji wykładni prawa, stwierdza, że „w aspekcie chronologicznym wykładnia językowa dokonywana jest w pierwszej kolejności. Po dokonaniu wykładni językowej należy w każdym przypadku dokonać wykładni funkcjonalnej. Jeżeli odwołanie się do dyrektyw językowych nie pozwala na wskazanie jednego znaczenia interpretowanego wyrażenia, wykładnia funkcjonalna służy dokonaniu wyboru jednego z nich jako właściwego. Jeżeli odwołanie się do reguł składniowych i znaczeniowych wskazuje na określone jedno znaczenie interpretowanego wyrażenia, to wykładnia funkcjonalna może albo potwierdzić to znaczenie jako właściwe, albo też - ale tylko w określonych sytuacjach - może być podstawą do odrzucenia tego znaczenia i przyjęcia innego znaczenia"58. Wskazane założenia metodologiczne dowodza, że dyrektywy interpretacyjne ${ }^{59}$ tworzą spójny i uporządkowany chronologicznie system, który wyznacza interpretatorowi określone postępowanie, „które nie ogranicza się do użycia jedynie językowych dyrektyw interpretacyjnych, ale nawet po otrzymaniu pozytywnego rezultatu ich zastosowania nakazuje jego sprawdzenie poprzez użycie pozostałych dyrektyw interpretacyjnych. Taka postawę interpretacyjną ilustruje paremia interpretatio cessat post applicationem trium typorum directionae" 60 .

Według twórcy derywacyjnej koncepcji wykładni prawa „dyrektywy celowościowe wskazuja, że jeżeli ktoś chce osiagnąć taki to a taki stan rzeczy, to powinien postapić w taki to a taki sposób. Dyrektywy te uzależniają więc z góry sposób określonego postępowania przede wszystkim od akceptacji wskazanego w nich celu. Zauważamy jednak, że dyrektywa celowościowa nie narzuca również akceptacji samego sposobu postępowania nawet przy akceptacji celu. Ktoś bowiem akceptując cel nadal pozostaje swobodny w akceptacji zastosowanego środka"61. Trzeba zaakcentować, że według derywacyjnej koncepcji wykładni prawa, a precyzyjniej wskazówek odnoszącej się do użycia dyrektyw celowościowych w percepcyjnej fazie wykładni, ustalenie celu może być dokonane w dwóch etapach, z czego pierwszy etap obejmuje trzy płaszczyzny rekonstrukcji normy prawnej, a drugi - dwie. W pierwszym etapie może to nastapić „przez odwołanie się do celów całego aktu (ratio iuris), sformułowa-

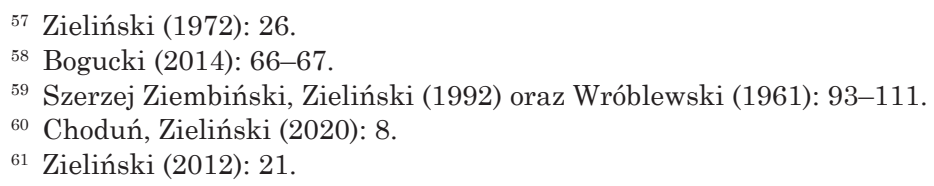


nego we wstępie tego aktu, a także w społecznie akceptowanych wartościach (a przez cele całego aktu do celu interpretowanego przepisu - ratio legis), przez odwołanie się do redukcyjnego rozumowania z danego przepisu o jego celu (np. z przepisu wprowadzającego ulgi podatkowe - o celach tych ulg), z pomocniczym uwzględnieniem tendencji celów, przejawionych w poprzednich regulacjach z danej dziedziny”" 62 W drugim etapie należy odwołać się do „ogólnej wiedzy naukowej z danej dziedziny wraz z jej prakseologicznym przełożeniem na osiagnięcie rezultatu merytorycznego (oparty na literaturze lub opinii ekspertów), zasad doświadczenia życiowego (nazywane również wiedzą potoczna). Uwaga: w obu przypadkach można uciec się w sprawach interpretacji do opinii biegłego z danej dziedziny"63.

Doktryna prawa zauważa, że w prawie administracyjnym rośnie obecnie rola wykładni funkcjonalnej jako jednego z etapów procesu wykładni oraz powiązanych z nią elementów wartościujących i ocennych ${ }^{64}$. W kontekście klasyfikacji metod wykładni Gizbert-Studnicki zauważa, że: „problematykę wykładni celowościowej rozpatruje się zwykle współcześnie w związku z szerszym zagadnieniem wykładni funkcjonalnej. Wykładnia funkcjonalna wyróżnia się tym od innych sposobów dokonywania wykładni, że interpretator bierze pod uwage tzw. kontekst funkcjonalny rozpatrywanego tekstu prawnego. W skład kontekstu funkcjonalnego wchodzą m.in. ustrój ekonomiczny i społeczno-polityczny, ogólna kultura społeczeństwa wyrażająca się w przyjętych w nim ocenach i normach, cele prawa danego tekstu prawnego lub poszczególnej normy prawnej, rozmaite zjawiska cywilizacyjne, w związku z którymi reguluje się zachowanie ludzi w społeczeństwie. Jeżeli wydzieli się cele prawa (tekstu prawnego, normy prawnej) jako wyróżniony składnik kontekstu funkcjonalnego, to uzasadnione wydaje się wyodrębnienie wykładni celowościowej jako

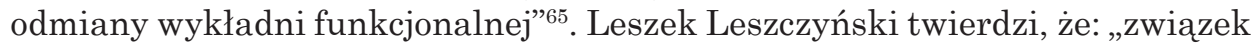
między oboma rodzajami reguł pozasystemowych nie prowadzi do ustalenia jednoznacznej relacji kolejności, chociaż nie może jej wykluczać. Wykładnia funkcjonalna może uzupełniać wykładnię celowościowa, ale może być też od niej niezależna, w pewnym sensie wobec niej alternatywna jako pozasystemowy argument interpretacyjny. Dostrzeganie aspektu dynamicznego w interpretowanym prawie czy też sytuacja głębokiej zmiany społecznej i transformacji prawnej usamodzielnia rolę argumentów funkcjonalnych w stosunku do celowościowych. [...] Oba argumenty (celowościowy i funkcjonalny) wiąża się z aksjologia, mogacca mieć ugruntowanie systemowe (zasady prawa), ale wskazują także na wartości pozasystemowe wiążące się z aksjologią społeczna lub polityczna”"66. Jakimowicz wskazuje, że: „metoda, zgodnie z która podczas interpretacji należy brać pod uwagę konsekwencje społeczne i ekonomiczne, do których prowadzić będzie określona interpretacja i wybrać interpretację prowadzącą do konsekwencji najbardziej korzystnych, odgrywa szczególnie

\footnotetext{
62 Wskazówka 35 - Zieliński (2012): 341.

${ }^{63}$ Wskazówka 36 - Zieliński (2012): 342.

${ }^{64} \mathrm{O}$ wzajemnych relacjach wartości do ocen - Ziembiński (1990): 57-60.

${ }^{65}$ Gizbert-Studnicki (1985): 52.

${ }^{66}$ Leszczyński (2015): 312-313.
} 
doniosła rolę w wypadku tych regulacji, gdzie prawo funkcjonuje jako instrument polityki społecznej (np. polityki gospodarczej, finansowej, ochrony środowiska, wychowawczej itd.), a zatem niewatpliwie na gruncie prawa administracyjnego" 67 .

Polityka ochrony środowiska ma charakter zintegrowany ${ }^{68}$, wynikające zaś z niej cele nakazuja, aby była ona spójna z innymi ogólnymi strategiami rozwoju kraju, tak by tworzyć warunki niezbędne do realizacji ochrony środowiska, zgodnie z zasadą zrównoważonego rozwoju. Zdaniem Ziembińskiego „dyrektywy funkcjonalne nakazują spośród dopuszczalnych na gruncie reguł znaczeniowych danego języka etnicznego sensów tekstu prawnego wybrać takie znaczenie zespołu przepisów, przy którym odtworzone na jego podstawie normy miałyby najsilniejsze uzasadnienie aksjologiczne $\mathrm{w}$ przyjmowanym systemie wartości”69. W derywacyjnej koncepcji wykładni prawa Zielińskiego dyrektywy funkcjonalne podlegaja zastosowaniu w fazie percepcyjnej wykładni po uprzednim skorzystaniu z dyrektyw językowych i systemowych ${ }^{70}$. Maja one za zadanie potwierdzić wynik wykładni językowej lub też mogą posłużyć do jego modyfikowania bądź też wyboru jednego z alternatywnych znaczeń. W związku z tym Leszczyński twierdzi, że „rezultat wykładni funkcjonalnej nie stanowi więc wyłącznie dyrektywy wyboru jednego ze znaczeń językowych, ale może tworzyć w określonych przypadkach odrębne znaczenie tekstu prawnego"71.

Jak zaznaczono wyżej, budowa strukturalna prawa ochrony środowiska charakteryzuje się tym, że cele i wartości oddziaływujące na kształt normy prawnej, zwłaszcza te wysłowione $\mathrm{w}$ zasadach prawa ${ }^{72}$, zakorzenione sa w unijnym porządku aksjologicznym, a ich konstrukcje normatywne spotykamy w systemach prawnych wszystkich krajów członkowskich. Występuje w tym przypadku zjawisko, które zostało określone przez Boguckiego jako „krzyżowe rozczłonkowanie aksjologiczne”. Polega ono na tym, że tak jak przepisy zawierające syntaktyczne i treściowe elementy jednej normy sa rozczłonkowane w aktach krajowych, a także unijnych, tak wartości składające się na ocenę globalną odpowiadające tej normie sa „rozczłonkowane” między prawem unijnym a prawem krajowym" ${ }^{\text {" } 3}$. Z tej przyczyny orzecznictwo Trybunału Sprawiedliwości Unii Europejskiej (TSUE) i wypracowane w nim reguły stosowania poszczególnych dyrektyw wykładni mogą być w niektórych przypadkach ważnym czynnikiem oddziałującym na proces interpretacji zachodzacy w krajowym porządku prawnym. Zdaniem Marka Safjana pewna uniwersalizacja standardu interpracyjnego wypływa z idei integracji europejskiej i sprowadza się „[...] do zbieżności wyników wykładni prawa, pomimo występowania na gruncie poszczególnych systemów nietożsamych konstrukcji

\footnotetext{
${ }^{67}$ Jakimowicz (2006): 432.

68 Szerzej Haładyj (2016): 87.

${ }^{69}$ Ziembiński (1980): 292.

${ }^{70}$ Zieliński (2012): 298-299.

${ }^{71}$ Leszczyński (2007): 33.

${ }^{72}$ Por. Łazor (2019): 631-648.

${ }^{73}$ Bogucki (2016): 179.
} 
normatywnych. Punktem odniesienie dla rekonstrukcji znaczeń zasad i wartości systemu stają się na przykład uniwersalne konotacje pojęć prawnych występujacych w prawie i orzecznictwie europejskim, ale też metody rozstrzygania konfliktu występujacego między zasadami systemu" ${ }^{4}$. W analizowanym przez autora orzecznictwie TSUE, które pojawiło się w ostatnich latach, można zaobserwować, że przy uzasadnieniu przyjęcia takiej, a nie innej interpretacji przepisu prawa Trybunał zazwyczaj wskazuje wprost na dyrektywy wykładni celowościowej, jako te, które przesądziły o przyjętym przez niego znaczeniu normy prawnej ${ }^{75}$. Szerszego wyjaśnienia zasad posługiwania się nimi w praktyce dostarcza nam fragment uzasadnienie opinii rzecznika generalnego Philipe’a Lègera przedłożonej Trybunałowi w sprawie C-350/0376. Konkluduje on, że: „[...] uważna analiza orzecznictwa pokazuje, że wykładnia celowościowa jest stosowana jedynie wtedy, gdy dany przepis można interpretować na wiele sposobów. Metoda ta jest często używana dla potwierdzenia znaczenia przepisu, który nie będąc całkiem jasnym i jednoznacznym, pozostawia jednak tylko niewiele miejsca na wątpliwości. W takim przypadku odwołanie się do brzmienia przepisu i do celów przepisów wspólnotowych spełnia w procesie wykładni funkcje pomocnicza. Wykładnia teleologiczna odgrywa także rolę, tym razem zasadnicza, kiedy dany tekst jest trudny do zinterpretowania w oparciu o same jego brzmienie"77. Przytoczony powyżej fragment opinii rzecznika generalnego Lègera potwierdza jedynie, że mimo że derywacyjna koncepcja wykładni prawa została uformowana na gruncie prawa polskiego, to jednak może ona znaleźć także praktyczne zastosowanie do interpretacji celowościowej przepisów prawa unijnego, nie zniekształcając równocześnie przyjętych w nim reguł znaczeniowych ${ }^{78}$. Za wskazaną tezą opowiada się również Andrzej Bator, który wychodzi nawet z założenia, że ten rodzaj wykładni jest charakterystyczny elementem $\mathrm{w}$ tym systemie prawa, ponieważ „w doktrynie prawa europejskiego często zwraca się uwagę na to, że wykładnia prawa UE nie eliminując innych znanych metod - jest zdominowana przez wykładnię funkcjonalną (celowościowa)"79.

Zaprezentowane powyżej uwarunkowania celowościowe i funkcjonalne, rozpatrywane także w kontekście zagwarantowania efektu wykładni prounijnej, dowodza, że derywacyjna koncepcja wykładni prawa ma charakter techni-

74 Safjan (2010): 274.

${ }^{75}$ Por. np. pkt 38 uzasadnienia wyrok Trybunału (siódma izba) z 26 listopada 2015 r. (wniosek o wydanie orzeczenia w trybie prejudycjalnym złożony przez Fóvarosi Kozigazgatasi es Munkaugyi Birósag - Węgry) - SC Total Waste Recycling SRL/Orszagos Kornyezetvedelmi es Termeszetvedelmi Fófelugyelóseg - sprawa C-487/14 (Dz. U. UE C 38, 1.2.2016: 9) oraz pkt 36 uzasadnienia Wyrok Trybunału (druga izba) z 3 kwietnia 2014 r. (wniosek o wydanie orzeczenia w trybie prejudycjalnym złożony przez Thüringer Oberlandesgericht - Niemcy) - Udo Rätzke przeciwko S+K Handels GmbH - sprawa C-319/13 (Dz. Ur. UE C 159, 26.5.2014: 10-11).

76 Opinia rzecznika generalnego Philipe'a Lègera z 28 września 2004 r. w sprawie C-350/03 (wniosek Landgericht Bochum o wydanie orzeczenia w trybie prejudycjalnym) Elisabeth Schulte $i$ Wolfgang Schulte przeciwko Deutsche Bausparkasse Baden AG (Zbiór Orzeczeń 2005 I-09215).

77 Ibid., pkt 85-91 (Zbiór Orzeczeń 2005 I-09232-09233).

78 Por. Radwański (2011): 2501-2511.

79 Bator (2015): 32. 
ki interpretacyjnej w pełni uniwersalnej, a co najważniejsze - zbudowana jest na zasadzie dyskursywności, co przejawia się w tym, że: , [...] mimo założonego $\mathrm{w}$ tej koncepcji postępowania interpretacyjnego wyznaczonego stosowaniem chronologicznie ułożonych dyrektyw interpretacyjnych, interpretator nie postępuje mechanicznie" ${ }^{80}$. Dlatego też daje to gwarancje precyzyjnego odtworzenia celów normy prawnej w obrębie prawa ochrony środowiska przy jednoczesnym zachowaniu hierarchii wartości, założonej zarówno przez prawodawcę krajowego, jak i unijnego.

\section{ZAKOŃCZENIE}

Ogólne ramy tematyczne niniejszego artykułu pozwoliły jedynie na zasygnalizowanie niektórych z zagadnień odnoszących się do uwarunkowań wykładni celowościowej w prawie ochrony środowiska. Główne cechy aksjologiczne tej gałęzi prawa, a także właściwości teoretycznoprawne samej koncepcji derywacyjnej, predestynują ją jako najbardziej adekwatne narzędzie w procesie rekonstrukcji jego norm prawnych. Trzeba podkreślić, że w prawie ochrony środowiska wzrasta obecnie rola wykładni celowościowej między innymi ze względu na dynamiczne zmiany zachodzące w obrębie jego wartości. Są one $\mathrm{z}$ reguły odpowiedzią na nowe kategorie zagrożeń środowiskowych (np. organizmy zmodyfikowane genetycznie), nasilenie zaś skali zagrożeń już występujących (np. zanieczyszczenie powietrza, zmiany klimatyczne) może skutkować zmianą hierarchii danej wartości w obowiązującym systemie aksjologicznym. W następstwie opisanych w artykule czynników wykładnia w prawie ochrony środowiska, a zwłaszcza jej kontekst celowościowy, jawi się jako jedno z kluczowych zagadnień mających wpływ na skuteczność normatywnie zdefiniowanych działań ochronnych. Trwający proces implementacji prawa unijnego w krajowym porządku prawnym i osadzenie jego instytucji, także w sferze regulacji prawa międzynarodowego, wymagaja, aby reguły stosowanej koncepcja wykładni potrafily sprostać tym dodatkowym wyzwaniom interpretacyjnym. Za zastosowanie koncepcji derywacyjnej do wykładni przepisów tworzących prawo ochrony środowiska przemawia w pierwszym rzędzie jej zintegrowany charakter. Spójność proponowanych zachowań interpretacyjnych przejawia się w aspekcie ich oryginalnej kompatybilności teoretycznoprawnej. Składaja się na nią nie tylko wzajemne powiązania tworzących jej podwaliny elementów wewnętrznych, lecz także i komponentów zewnętrznych, takich jak dorobek całego prawoznawstwa polskiego, czy nawet inne koncepcje wykładni i osiagnięcia badawcze ${ }^{81}$.

Uzasadnieniem wyboru przeze mnie tej, a nie innej drogi do interpretacji celowościowej przepisów wchodzących w skład prawa ochrony środowiska niech będzie również stanowisko Jakimowicza. Uznał on bowiem, że „analiza

${ }^{80}$ Choduń, Zieliński (2020): 12.

81 Szerzej Zieliński (2006): 94. 
cech prawa administracyjnego i ich wpływu na model stosowania prawa przez organy administracji publicznej prowadzi do wniosku o zasadności przyjęcia na gruncie tej gałęzi prawa większości elementów tzw. derywacyjnej koncepcji wykładni”82. Jedna z metodologicznie fundamentalnych cech tej koncepcji, jakże istotnej w sferze władztwa administracyjnego, jest to: „iż zasady postępowania interpretacyjnego wyznaczone sa nie przez zachowania interpretatora, lecz przez rzeczywiste cechy tekstów prawnych, które odpowiednio rozpoznane narzucają taki, a nie inny sposób postępowania interpretacyjnego"83. Poczynione w niniejszym opracowaniu rozważania niech staną się w doktrynie prawa przyczynkiem do bardziej szczegółowych badań nad zagadnieniem stosowania określonych dyrektyw wykładni prawa w procesie rekonstrukcji norm prawa ochrony środowiska.

Barczak, A., Łazor, M., Ogonowska, A. (2018). Oceny oddziaływania na środowisko w prawie polskim. Ze wzorami dokumentów i schematami. Warszawa.

Bator, A. (2015). O adekwatności założeń derywacyjnej koncepcji wykładni do badań na interpretacją prawa Unii Europejskiej. Studia Prawa Publicznego 10: 11-34.

Boć, J. (2015). Prawo ochrony środowiska jako prawo publiczne, [w:] J. Korzeniowski (red.), Zagadnienia systemowe prawa ochrony środowiska. Łódź: 17-27.

Bogucki, O. (2010). Odtwarzanie celów i innych wartości z tekstu prawnego, [w:] A. Choduń, S. Czepita (red.), W poszukiwaniu dobra wspólnego. Księga jubileuszowa Profesora Macieja Zielińskiego. Szczecin: 195-213.

Bogucki, O. (2014). Teorie języka a pluralizm wartości w kontekście teorii wykładni prawa. Ruch Prawniczy, Ekonomiczny i Socjologiczny 76(4): 55-67.

Bogucki, O. (2015). Sposoby pojmowania „historyczności” wykładni prawa. Państwo i Prawo 70(9): $34-52$.

Bogucki, O. (2016). Model wykładni funkcjonalnej w derywacyjnej koncepcji wykładni prawa. Szczecin.

Bogucki, O. (2020). Rola wartości w interpretacji prawa. Ujęcie normatywne. Archiwum Filozofii Prawa i Filozofii Społecznej: 96-108.

Bukowski, Z. (2017). Aksjologiczne podstawy stanowienia prawa ochrony środowiska, [w:] J. Zimmermann (red.), Aksjologia prawa administracyjnego. Tom 2. Warszawa: Wolters Kluwer 233-241.

Ciechanowicz-McLean, J. (2007). Interes publiczny w prawie ochrony środowiska, [w:] J. Dobkowski (red.), Problemy współczesnego ustrojodawstwa. Księga Jubileuszowa Profesora Bronisława Jastrzębskiego. Olsztyn: 452-459.

Choduń, A. (2015). Maciej Zieliński (deriverate) concept of legal interpretation. Studia Prawa Publicznego 10(2): 111-125.

Choduń, A. (2016). Koncepcja wykładni prawa Macieja Zielińskiego. Ruch Prawniczy, Ekonomiczny i Socjologiczny 78(4): 57-67.

Choduń, A. (2018). Aspekty językowe derywacyjnej koncepcji wykładni prawa. Uniwersytet Szczecińskie Rozprawy i Studia 1012. Szczecin.

Choduń, A., Zieliński, M. (2020). Uzasadnienie twierdzeń interpretacyjnych z perspektywy derywacyjnej koncepcji wykładni prawa. Archiwum Filozofii Prawa i Filozofii Społecznej 2(23): $7-18$.

Czepita, S. (2000). Konstytucja a teoria prawa. Ruch Prawniczy, Ekonomiczny i Socjologiczny 62(2): 187-196.

Dunaj, B. (1996). Słownik współczesnego języka polskiego. Warszawa.

Gizbert-Studnicki, T. (1985). Wykładnia celowościowa. Studia Prawnicze 3/4: 51-69.

82 Jakimowicz (2006): 377.

${ }^{83}$ Smolak (2016): 103. 
Gizbert-Studnicki, T. (1989). Konflikt dób i kolizja norm. Ruch Prawniczy, Ekonomiczny i Socjologiczny 51(1): 1-15.

Haładyj, A. (2016). Polityka ochrony środowiska - polityka sektorowa czy zintegrowana? Przegląd Prawa Publicznego 9(114): 77-88.

Helios, J., Jedlecka, W. (2018). Wykładnia prawa Unii Europejskiej ze stanowiska teorii prawa. Wrocław.

Jakimowicz, W. (2006). Wykładnia w prawie administracyjnym. Warszawa.

Jastrzębski, L. (1976). Ochrona prawna przyrody i środowiska w Polsce. Zagadnienia administracyjne. Warszawa.

Kanarek B., Zieliński, M. (2001). Porządkująca faza wykładni. Ruch Prawniczy, Ekonomiczny i Socjologiczny 63(3): 1-12.

Komierzyńska, E., Zdyb, M. (2016). Klauzula interesu publicznego w działaniach administracji. Annales Universitatis Mariae Curie-Skłodowska 63(2): 161-179.

Kordela, M. (2017). Aksjologiczna wykładnia prawa. Przegląd Prawa i Administracji 101: 149-158.

Korzeniowski, P. (2010). Zasady prawne ochrony środowiska. Łódź.

Korzeniowski, P. (2012). Bezpieczeństwo ekologiczne jako instytucja prawa ochrony środowiska. Łódź.

Korzeniowski, P. (2015). Pojęcie „środowisko jako dobro wspólne” w systemie prawa ochrony środowiska. Zeszyty Naukowe Sądownictwa Administracyjnego 58(1): 24-36.

Korzeniowski, P. (2017). Idea wartości uniwersalnych w prawie ochrony środowiska, [w:] J. Zimmermann (red.), Aksjologia prawa administracyjnego. Tom 2. Warszawa: 242-258.

Kotarbiński, T. (1975). Traktat o dobrej robocie. Warszawa.

Kwiecień, R. (2011). Teoria i filozofia prawa międzynarodowego. Problemy wybrane. Warszawa.

Leszczyński, L. (2007). O charakterze dyrektyw wykładni. Państwo i Prawo 62(3): 28-44.

Leszczyński, L. (2015). Wykładnia celowościowo-funkcjonalna przepisów prawa administracyjnego, [w:] R. Hauser, A. Wróbel, Z. Niewiadomski (red.), System prawa administracyjnego. Tom 4: Wykładnia w prawie administracyjnym. Warszawa: 283-322.

Lipowicz, I. (2017). Dobro wspólne. Ruch Prawniczy, Ekonomiczny i Socjologiczny 79(3): 17-31.

Łazor, M. (2019). Zasada „zanieczyszczający płaci” administracyjnoprawnym standardem w gospodarce odpadami, [w:] Z. Duniewska, A. Rabiega-Przyłęcka, M. Stahl (red.), Standardy współczesnej administracji i prawa administracyjnego. Warszawa: 631-648.

Mikołajewicz, M. (2015). On the maxim of clara non sunt interpretanda. Studia Prawa Publicznego 10(2): 77-89.

Meszorer, A. (1958). O Szymonie Rundsteinie. Palestra 2: 89-93.

Mularski, K. (2017). Faza rekonstrukcyjna derywacyjnej koncepcji wykładni - próba krytycznej analizy. Studia Prawnicze 3(211): 7-46.

Piszko, R. (2002). Deformacja reguł wykładni w praktyce wykładni przepisów prawnych. Gdańskie Studia Prawnicze 2: 141-148.

Pulka, Z. (2018). Wykładnia prawa jako działanie optymalizacyjne. Przegląd Prawa i Administracji 120: 79-94.

Radwański, Z. (2011). Derywacyjna koncepcja wykładni polskiego prawa prywatnego a wykładnia prawa Unii Europejskiej, [w:] J. Gudowski, K. Weitz (red.), Aurea praxis. Aurea theoria. Księga pamiątkowa ku czci Profesora Tadeusza Erecińskiego. Tom 2. Warszawa: 2501-2511.

Rakoczy, B. (2018). Wykładnia in dubio pro naturam w prawie polskim. Studia Prawnicze KUL 74(2): 87-99.

Romanowicz, M. (2011). Teoria klaryfikacyjna wykładni prawa jako teoria uzasadnienia. Perspektywa psycholingwistyczna a pozytywistyczna koncepcja wykładni. Archiwum Filozofii Prawa i Filozof Społecznej 1: 55-74.

Rakoczy, B. (2018). O publiczny i prywatnym prawie ochrony środowiska. Samorząd Terytorialny 1/2: $18-25$

Rundstein, S. (1904). Studya i szkice prawne. Lwów.

Rundstein, S. (1916). Wykładnia prawa i orzecznictwo. Przyczynki metodologiczne. Warszawa.

Safjan, M. (2010). Uniwersalizacja wykładni prawa, [w:] A. Choduń, S. Czepita (red.), W poszukiwaniu dobra wspólnego. Księga jubileuszowa Profesora Macieja Zielińskiego. Szczecin: $271-298$. 
Smolak, M. (1998). Zmiana paradygmatu interpretacyjnego w okresie transformacji ustrojowej w Polsce. Ruch Prawniczy, Ekonomiczny i Socjologiczny 60(3/4): 21-33.

Smolak, M. (2012). Wykładnia celowościowa z perspektywy pragmatycznej. Warszawa.

Smolak, M. (2014). Aksjologiczne założenia stosowania dyrektyw wykładni celowościowej. Ruch Prawniczy, Ekonomiczny i Socjologiczny 76(1): 5-12.

Smolak, M. (2016). Ujednoznacznienie treści norm prawnych w procesie wykładni prawa, [w:] M. Hermann, S. Sykuna (red.), Wykładnia prawa. Tradycje i Perspektywa. Warszawa: 101114.

Stelmasiak, J. (1994). Miejscowy plan zagospodarowania przestrzennego jako prawny środek ochrony środowiska. Lublin.

Stelmasiak, J. (2013). Interes indywidualny a interes publiczny w ochronie środowiska w obszarze specjalnym o charakterze ekologicznym. Rzeszów.

Wronkowska, S., Ziembiński, Z. (2001). Zarys teorii prawa. Poznań.

Wróblewski, J. (1959). Zagadnienie wykładni prawa ludowego. Warszawa.

Wróblewski, J. (1961). Właściwość, rola i zadania dyrektyw interpretacyjnych. Ruch Prawniczy, Ekonomiczny i Socjologiczny 23(4): 93-111.

Wróblewski, J. (1973). Wartość a decyzja sądowa. Ossolineum Wrocław.

Wszołek, P. (2011). O metodach badawczych stosowanych w nauce prawa administracyjnego dla poznania prawa jako wypowiedzi normatywnej. Przegląd Prawa Publicznego 7/8: 9-43.

Zieliński, M. (1972). Interpretacja jako proces dekodowania tekstu prawnego. Poznań.

Zieliński, M. (1998). Wyznaczniki reguł wykładni prawa. Ruch Prawniczy, Ekonomiczny i Socjologiczny 50(3/4): 1-20.

Zieliński, M. (2006). Derywacyjna koncepcja wykładni prawa jako koncepcja zintegrowana. Ruch Prawniczy, Ekonomiczny i Socjologiczny 68(3): 93-101.

Zieliński, M. (2012). Wykładnia prawa. Zasady, reguły, wskazówki. Warszawa.

Zieliński, M., Ziembiński, M. (1998). Uzasadnienia twierdzeń, ocen i norm w prawoznawstwie. Warszawa.

Zieliński, M., Zirk-Sadowski, M. (2011). Klasyfikacyjność i derywacyjność w integrowaniu polskiej teorii wykładni prawa. Ruch Prawniczy, Ekonomiczny i Socjologiczny 73(2): 99-111.

Ziembiński, Z. (1990). Wstęp do aksjologii dla prawników. Warszawa.

Ziembiński, Z., Zieliński, M. (1992). Dyrektywy i sposób ich wypowiadania. Warszawa.

Żurawik, A. (2013). „Interes publiczny”, „interes społeczny” i „interes społecznie uzasadniony”. Ruch Prawniczy, Ekonomiczny i Socjologiczny 75(2): 57-69.

Zimmermann, J. (2015). Wprowadzenie, [w:] J. Zimmermann (red.), Wartości w prawie administracyjnym. Warszawa: 11-16.

\section{A FEW WORDS ON TELEOLOGICAL INTERPRETATION IN ENVIRONMENTAL LAW}

\section{Sum mary}

Environmental law is one of the few branches of law in which we can currently observe the increasing role of teleological interpretation. The system of values that affects this process has been changing dynamically, due to the type and scales of existing environmental hazards. Erroneous goal identification, or ignoring the goals altogether, while analysing grey areas of interpretation concerning legal standards, may interfere with, or even paralyse, the functioning of certain legal institutions. In practice, this translates to an increased level of environmental hazards. The significance of the axiological context means that the aim of this paper is not only to highlight the importance of teleological interpretation in this area but also to draw attention to the applicability of a particular interpretation scheme. The background of this study is a general analysis of the system of values and objectives present in environmental law and their reference to the relevant views and concepts established in the theory of law. The applied research method is based mainly on a review of the main teleological assumptions in Maciej Zieliński's derivative conception of legal interpretation and an attempt to juxtapose them with 
the statements of the environmental law doctrine relating to the purpose of a legal norm. The adopted construction aims to substantiate the thesis that Zieliński's derivative concept of legal interpretation may be the most accurate tool for interpreting environmental law norms. Its theoretical-legal structure, referring in particular to the reconstruction of objectives and other values from the legal text, confirms the indicated research assumption.

Keywords: environmental law; interpretation of law; values; teleological interpretation 